rate. These factors will force the adoption of this kind of program sometime in the future. We who are charged with the responsibility for development of the range and related resource should take the leadership in developing such a program. We should take the leadership while there is still time for early planning and development of the range resource, for wise use in the long run.

\section{Effects of Drouth on Mesquite}

\author{
Meril G. Carter \\ Area Conservationist \\ Soil Conservation Service \\ U. S. Dept. of Agriculture \\ Austin, Texas
}

Comments from old time ranchers and historical documentation (Inglis, 1961) indicate a substantial increase of thorny type brush including mesquite (Prosopis glandulosa Torr.) in south and southwest Texas during the past hundred years. A fairly common expression among the older ranchers is, "We used to dig for firewood," referring to the digging of mesquite roots in the then treeless grasslands. Likewise, "In those days we could see a cow for miles," is often volunteered in commenting on the dense stands of mesquite now occupying the same land.

The spread of mesquite has been attributed to many causes, with over-grazing, trailing, and associated soil and cover disturbances as the principal mechanisms. The effects of fire in both suppressing and opening the way to invasion of mesquite are also cited (Parker, 1952). A few authors refer to drouth, particularly in its adverse effects on grass competition (Young, 1948), as a major climatic hazard favoring spread of mesquite.

There is little in the literature on the direct effects of drouth in eliminating or reducing invaded or residual stands of mesquite in south Texas.

\section{Drouth Kills Mature Mesquite}

During the period 1950 to 1963 , observations were made of the effects of drouth on mesquite in an eleven county area of the westernmost South Texas Plains comprising $7,500,000$ acres of mesquite infested rangelands. The period of observation coincided with the most severe drouth on record from 1950 through 1956 (Waldrip, 1957). Rainfall dur-

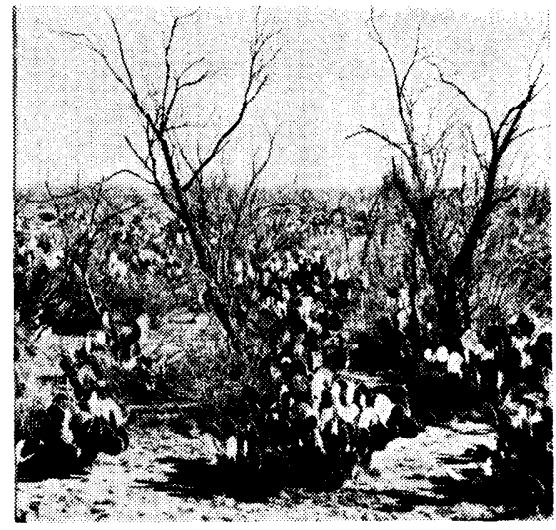

Figure 1. Overstory of drouth killed mesquite with a living understory of Opuntia, Acacia, and Aloysia species. SCS Photo.

ing these seven years amounted to 64 to 75 percent of normal, depending on location. Effective precipitation, based on rainfall at Carrizo Springs (Dimmitt County) of amounts greater than one inch, amounted to less than eight inches per year for seven years. Average rainfall for the area is 18 to 28 inches, from west to east.

The resistance of mesquite to drouth is well known. Notwithstanding, substantial kills of mature mesquite were observed on all range sites under all range conditions except on gravelly soils. The shrubs were considered dead when no resprouting occurred within two years after the end of the drouth. Losses, while not area wide or of all age classes, were general throughout the area. Hardest hit stands occurred on Leona clay and Frio silty clay loam bottomland sites and Montell clay flat and saline clay sites. Uvalde silty clay loam, Maverick clays, Monteola clays and Duval fine sandy loam upland sites also showed considerable losses. The kill of mesquite on these sites approached 40 percent.

Counts of dead and live plants on line transects showed some interesting ecological phenomena. Broad bottomland sites on the Nueces River near Crystal City (Zavala County), where overflow could be expected at least once every 5 years but did not occur during the drouth, showed 75 percent death loss of mature trees. Narrower bottoms receiving some overflow showed no observable losses. Immature mesquite with stem diameters of 1 to 3 inches either in pure stands or mixed with larger trees withstood the drouth on all range sites. Most such plants appear unaffected in 1964.

Mesquite stands of all age classes that were previously chained for control and subsquently branched out at ground level were largely unaffected by drouth. Young mesquite on areas rootplowed in former years showed no mortality. Mature untouched stands of mesquite with understories of heavy grass suffered greater drouth kill than on overgrazed areas on the Captain Burr Ranch in Maverick County. Strangely enough, there was little drouth kill of mesquitc on accidentally burned heavily grassed areas near La Pryor (Zavala County) on Uvalde silty clay loam site. Mature scattered trees on saline soils on the Burr Ranch were largely killed by drouth, yet multistemmed plants or young trees escaped.

Understories of associated brush including species of Acacia, Condalia, Opuntia, Aloysia, Celtis and Rhamnus on most sites were thinned out or died back to the bud crown. Plants of these genera were rarely killed and made rapid recovery. In 1964, such areas present a living understory aspect with a dead mesquite overstory.

Large scale mortality of mesquite apparently requires several consecutive years of drouth since most kill took place during the last two years of the drouth. It follows that severe drouths of one to two years' duration would have little effect in south Texas as confirmed in the severely dry years of 1961-62 when no observable losses occurred.

Brush control methods, both mechanical and chemical, have been used for many years in south Texas (Davis, 1961) on mesquite and asso-

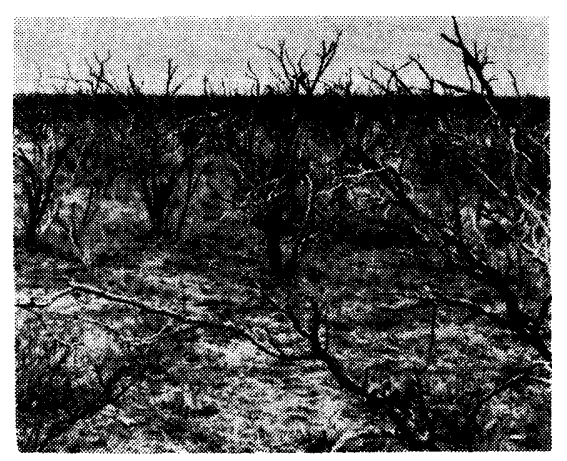

Figure 2. Near total drouth kill of mesquite on clay flat range site. Winter Garden Soil Conservation District Photo. 
ciated brush. Such efforts, though extensive, have resulted in less elimination of mesquite than the drouth of 1950-56.

\section{Conclusion}

The seven years of record breaking drouth from 1950 through 1956 eliminated or thinned out large areas of mesquite on nearly all range sites in a large area of the South Texas Plains. Young trees or trees with several stems resulting from chaining for control were largely unaffected by drouth. Although grass competition appeared to hasten the mortality of mesquite, substantial kills were noted on all degrees of range condition. Since early day ranchers once dug mesquite stumps for firewood in what were open grasslands at the time, it appears reasonable to suppose that recurring severe drouths must be considered as a natural control for mesquite.

Considering the time span that mesquite has been on hand to spread and occupy grasslands, extended drouths may account for the natural advance and retreat of mesquite into grasslands, similar to the better known advances and retreats of forest species into prairie soils. Human manipulations of rangeland environments with grazing animals have obscurcd the natural ebb and flow of mesquite but generally in favor of wider dispersal.

\section{Literature Cited}

Davis, Richard B. 1961. Effects of brush control on wildlife in the Rio Grande Plain. Federal Aid Project No. W-84-R-1. Texas Game and Fish Commission. Job No. 3. $21 \mathrm{pp}$.

INGLIS, JACK M., AND RICHARD B. Davis. 1961. Effects of brush control on wildlife in the Rio Grande Plain. Federal Aid Project No. W-84-R-2. Texas Game and Fish Commission. Job No. 1. 84 pp.

Parker, KenNeth W., AND S. Clark Martin. 1952. The mesquite problem on southern Arizona ranges. U. S. Dept. Agr. Circ. 908. 70 pp.

Waldrip, Williaim J. 1957. Farming and ranching risk as influenced by rainfall. III Rio Grande Plain of Texas. Texas Agr. Exp. Sta. Misc. Publ. 241. $35 \mathrm{pp}$.

Young, Vernon A, Frank R. AnderWald, AND Wayne G. McCully. 1948. Brush problems on Texas ranges. Texas Agr. Exp. Sta. Misc. Publ. 21. 19 pp. 